Note

\title{
Efficient double glycoconjugation to naturalize high molecular weight disperse dyes ${ }^{i}$
}

\author{
Roberto Bianchini ${ }^{\mathrm{a}, *}$, Massimo Rolla ${ }^{\mathrm{a}}$, Jalal Isaad ${ }^{\mathrm{a}}$, Giorgio Catelani ${ }^{\mathrm{b}, *}$, Lorenzo Guazzelli ${ }^{\mathrm{b}}$, \\ Massimo Corsi ${ }^{a}$, Marco Bonanni ${ }^{\text {a }}$ \\ a Dipartimento di Chimica 'Ugo Schiff', Università di Firenze, via della Lastruccia 13, Sesto Fiorentino 50019 (FI), Italy \\ ${ }^{\mathrm{b}}$ Dipartimento Scienze Farmaceutiche, Università di Pisa, via Bonanno 33, Pisa 56126, Italy
}

\section{A R T I C L E I N F O}

\section{Article history:}

Received 23 August 2011

Received in revised form 21 October 2011

Accepted 23 October 2011

Available online $\mathrm{xxxx}$

\section{Keywords:}

Disperse azodyes

Glycoconjugation

Glutamic acid

Lactose

\begin{abstract}
A B S T R A C T
Commercially available Disperse Orange 29 (1a) and Disperse Red 1 (2a) were elaborated to glycoconjugated species, following a new version of a previously-described 'naturalisation' procedure. Glutamic acid was chosen to achieve a double glycoconjugation, which is essential to give to the original disperse dye a water solubility suitable for reaching optimal dyeing conditions. UV-vis plot of the 'naturalised' species showed negligible differences when compared to those of the commercial dyes.
\end{abstract}

(C) 2011 Elsevier Ltd. All rights reserved.
The naturalisation of dyes ${ }^{1}$ (i.e., the conjugation of dyes to saccharide species) has proven to be a valid method to prepare novel dyeing agents. The main characteristics of these dyes are not only their solubility in water, but also their ability to dye the majority of synthetic and natural (wool, cotton) textiles. ${ }^{2}$ Moreover this property is accompanied by the environmentally sound characteristic: the overall process of dyeing does not require surfactants, mordants, dispersing agents or other additives, generally required to yield a good permeation of the dye into the fabrics. ${ }^{3}$

A limitation of the solubilising power of the saccharidic unit when conjugated with the dye, is that the molecular weight of the two portions must remain similar. ${ }^{4}$ We have observed that large molecular sized dyes do not reach an acceptable hydrosolubility when glycoconjugated with a single lactose unit, despite the presence of a variety of linkers such as esters, ethers, amides, alkylamino derivatives and mixed ethereal-esters, or amido-esters. ${ }^{4}$ To extend the field of application of this new type of dyeing agent, we studied a double glycoconjugation with lactose, bonded through a difunctional linker to the chromophore. This should enhance the solubilising power of the saccharide according to the molecular weight of the dye.

Part of this work has been presented in preliminary form at XVI European Carbohydrate Symposium, Sorrento (I), 3-7 July 2011, abstract PO054.

* Corresponding authors. Tel.: +39 0554573486; fax: +39 0554573531 (R.B.); tel +39 0502219700; fax: +39 0502219660 (G.C.).

E-mail addresses: roberto.bianchini@unifi.it(R. Bianchini), giocate@farm.unipi.it, giorgio.catelani@farm.unipi.it (G. Catelani).
As a first example of this approach we recently prepared malonic acid derivatives. ${ }^{1 \mathrm{c}, \mathrm{d}}$ Herein, we highlight that glutamic acid is a particularly convenient functionality to link chromophoric moieties to saccharides in the form of water soluble dyes. The procedure allows the preparation of new materials able to dye and to reduce the environmental impact of the waste produced by dyeing. ${ }^{5}$

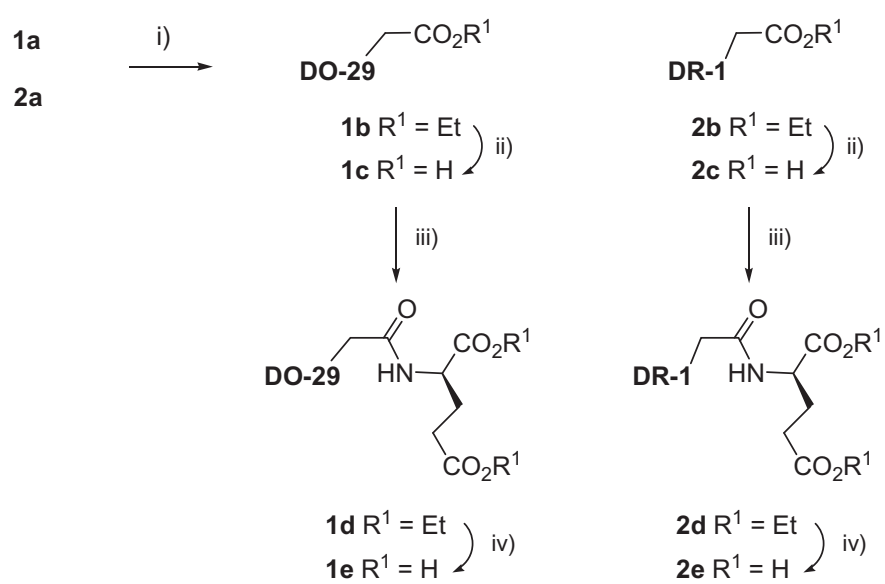

Scheme 1. Preparation of glutamic acid derivatives (1e) and (2e). Reagents and conditions: (i) (1b): $\mathrm{KOH}, 18$-crown-6, $\mathrm{BrCH}_{2} \mathrm{CO}_{2} \mathrm{Et}, \mathrm{THF}, 0{ }^{\circ} \mathrm{C}, \mathrm{rt}, 8 \mathrm{~h}, 91 \%$; (2b): $\mathrm{NaH}$, $\mathrm{BrCH}_{2} \mathrm{CO}_{2} \mathrm{Et}, \mathrm{THF}, 0^{\circ} \mathrm{C}-\mathrm{rt}, 8 \mathrm{~h}, 72 \%$; (ii) $\mathrm{KOH}, \mathrm{THF}, \mathrm{H}_{2} \mathrm{O}$, rt, $98 \%$ (1c) $84 \%$ (2c); (iii) (1d) (1) ClCOEt, TEA, THF; (2) diethyl glutamate. $\mathrm{HCl}, \mathrm{TEA}, 90 \%$; (2d): (1) $\mathrm{SOCl}_{2}$, TEA; DCM; (2) diethyl glutamate $\mathrm{HCl}$, TEA, 90\%; (iv) $\mathrm{KOH}, \mathrm{THF}, \mathrm{H}_{2} \mathrm{O}$, rt, $98 \%$ (1e) $96 \%$ (2e). 
The synthetic path to obtain multiple glycoconjugated dyes (Scheme 1) was developed for two commercially available products: Disperse Orange 29 and Disperse Red 1 (Fig. 1).

Ethyl 2-bromoacetate was used in the presence of a base of suitable strength to set up a useful tag for glutamic acid coupling. Subsequent hydrolysis of the ester groups of $\mathbf{1 b}$ and $\mathbf{2 b}$ led to carboxylic acid derivatives $\mathbf{1 c}$ and $\mathbf{2 c}$ in good yields. The acid groups were activated and coupled with glutamic acid, as the corresponding diethyl ester. In the case of 1c, ethyl chloroformate ${ }^{6}$ was used to assemble a mixed ethyl-acetyl carbonate, and compound 1d was obtained in good yields. For 2c, better results were obtained with thionyl chloride, ${ }^{7}$ and compound 2d was achieved in excellent yield. Both glutamic diester derivatives 1d and 2d were hydrolysed to dicarboxylic acids $\mathbf{1 e}$ and $\mathbf{2 e}$ completing the elaboration of dyes 1a and 2a (Scheme 1).

The naturalising lactose derivative $\mathbf{4}$ was prepared through a straightforward elaboration ${ }^{8}$ of lactose-triacetonide $\mathbf{3}$, synthesised from lactose according to a well established protocol. ${ }^{9}$ Toluensulfonyl chloride was employed to regioselectively introduce a good leaving group on the primary hydroxyl group of $\mathbf{3}$. The subsequent $\mathrm{S}_{\mathrm{N}} 2$ displacement with sodium azide and the final hydrogenolysis afforded 6'-amino-lactose-triacetonide 4 in $80 \%$ yield over three steps (Scheme 2). ${ }^{8}$

The coupling of the elaborated dye and saccharide moieties was carried out using as the acid activating reagent 4-(4,6-dimethoxy1,3,5-triazin-2-yl)-4-methylmorpholinium chloride (DMTMM), prepared in situ by reaction of 2-chloro-4,6-dimethoxy-1,3,5-triazine with $\mathrm{N}$-methyl morpholine. ${ }^{10}$ Compounds $\mathbf{1 e}$ and $\mathbf{2 e}$ were then converted to the corresponding bis-6'-amino-lactose-triacetonide glutamic derivatives $\mathbf{1 f}$ and $\mathbf{2 f}$ in acceptable to excellent yields thus confirming the validity of the reaction strategy (Scheme 3 ).

Final removal of the acetal groups using TFA ${ }^{1}$ afforded the target compounds $\mathbf{1 g}$ and $\mathbf{2 g}$ (Scheme 4).

These new naturalised dyes have similar chromophoric properties compared with the non-glycoconjugated species 1a and 2a (Fig. 1). The intensities are comparable and for the $\lambda_{\max }$ absorption the shifts are 2 or $3 \mathrm{~nm}$. The maximum difference observed is between the $\varepsilon_{\max }$ of dye 2a and its double glycoconjugated version $\mathbf{2 g}$ which was found to be around 1\% (Fig. 2).

In conclusion, the strategy here reported, which employs glutamic acid as linker between the chromophore and the sugar furnishes chemically stable final naturalized dyes, thanks to the ethereal and amidic bonds. Currently, progress to extend this methodology to other saccharide derivatives is under investigation.

\section{Experimental}

\subsection{General methods}

Thin layer chromatography (TLC) was performed using commercially prepared 60-mesh silica gel aluminium foils (Merck; $60 \AA ̊$ F254) and spots were visualized with: (a) UV light (254 and $366 \mathrm{~nm}$ ), (b) an acidic solution of $p$-anisaldehyde in ethanol. Flash column chromatography (FCC) was carried out on Merck Silica Gel

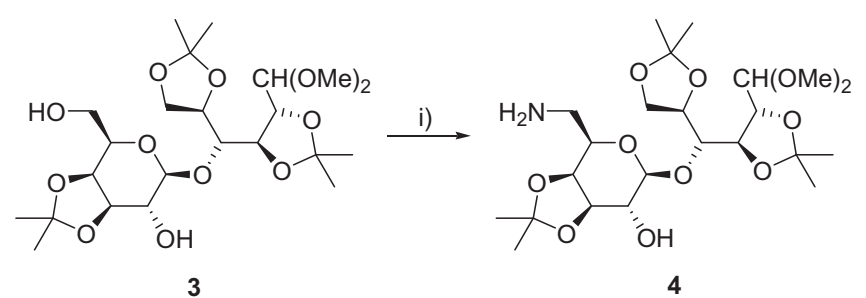

Scheme 2. Synthesis of 6'-aminotriacetonlactose dimethyl acetal (4). Reagents and conditions: (i) (1) pyridine, $\mathrm{MeCN}, p \mathrm{TsCl}, 0{ }^{\circ} \mathrm{C}-\mathrm{rt}$, ovn, $92 \%$; (2) $\mathrm{NaN}_{3}, \mathrm{DMSO}, 90{ }^{\circ} \mathrm{C}$, 20 h, $91 \%$; (3) $\mathrm{H}_{2}, \mathrm{Pd} / \mathrm{C}, \mathrm{MeOH}, \mathrm{rt}, \mathrm{ovn}, 96 \%$.

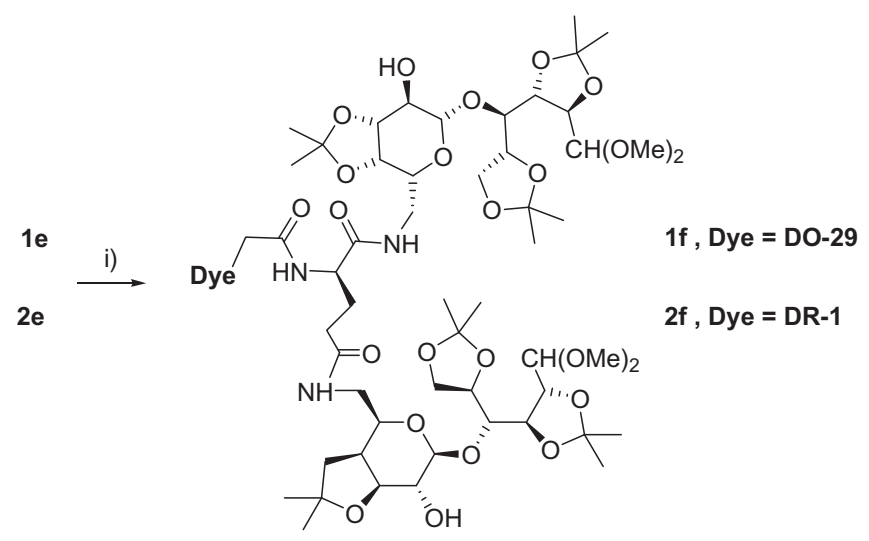

Scheme 3. Synthesis of bis-lactose glutamic amide derivatives (1f) and (2f). Reagents and conditions: (i) DMTMM, THF, $0{ }^{\circ} \mathrm{C}$ to room temperature, overnight, 91\% (1f):60\% (2f).

60 (230-400 mesh) according to Still et al. ${ }^{11}{ }^{1} \mathrm{H}$ and ${ }^{13} \mathrm{C}$ NMR spectra were recorded at $200 \mathrm{MHz}$, on Varian spectrometers in deuterated solvents and are reported in parts per million (ppm) with solvent resonance used as internal reference. When not specified spectra are referred to mixtures of enantiomers, or diastereoisomers. Mass spectra were taken from ThermoFisher LCQ-Fleet ion trap instrument and spectra were registered with ESI $+c$ technique. Elemental analysis was carried out on a Perkin Elmer 240 C Elemental Analyzer. UV-vis spectra were recorded on a Cary-4000 Varian spectrophotometer. The industrial dye 4-[2-methoxy-4(4'-nitrophenylazo)phenylazo]-phenol 1a (Colour Index name: Orange 29) and $N$-ethyl- $N$-(2-hydroxyethyl)-4-(4-nitrophenylazo)aniline 2a (Colour Index name: Disperse Red 1) are commercially available (Sigma-Aldrich) and used as such.

\section{2. $6^{\prime}$-Deoxy-6' amino-2,3:5,6:3', $\mathbf{4}^{\prime}$-tri-O-(isopropylidene)lactose dimethyl acetal (4)}

A solution of protected lactose $3^{9}(2.00 \mathrm{~g}, 3.92 \mathrm{mmol})$ in pyridine/acetonitrile $2: 1(15 \mathrm{~mL}$ ) was added dropwise to a solution of para-4-methylbenzene-1-sulfonyl chloride ( $\mathrm{TsCl}) \quad(0.90 \mathrm{~g}$, $4.70 \mathrm{mmol})$ in pyridine/acetonitrile $2: 1(3 \mathrm{~mL}){ }^{8}$ The reaction mixture was stirred at room temperature overnight, then water

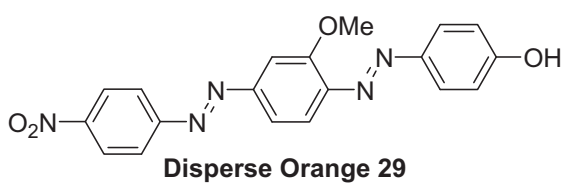

$1 \mathrm{a}$

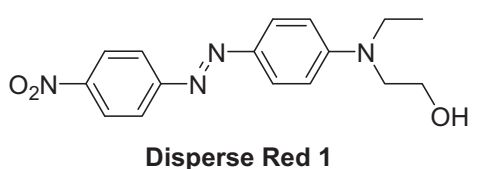

$2 a$

Figure 1. Disperse dyes employed for naturalisation. 


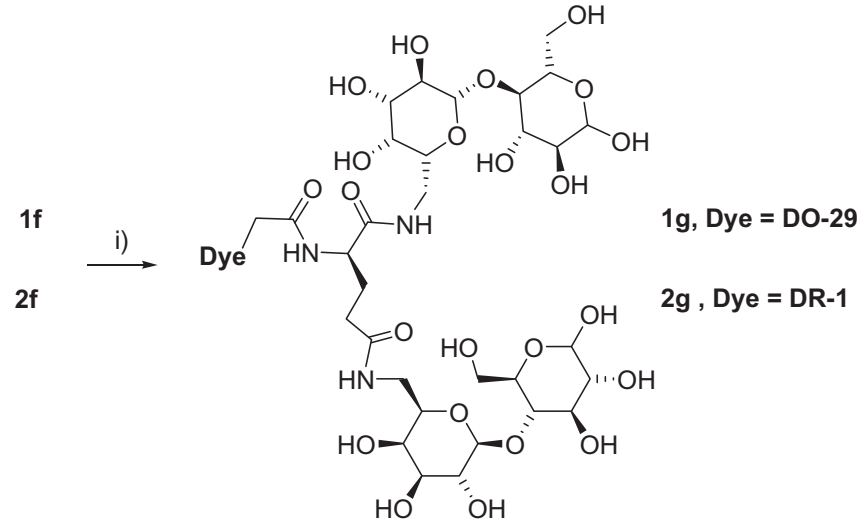

Scheme 4. Synthesis of naturalized dyes (19) and (2g). Reagents and conditions: (i) TFA, $\mathrm{H}_{2} \mathrm{O}$, rt, ovn, 99\% (19):78\% (2g).

$(20 \mathrm{~mL})$ and ether $(20 \mathrm{~mL})$ were added to the crude solution and the aqueous phase was separated and extracted with $\mathrm{Et}_{2} \mathrm{O}$ $(2 \times 20 \mathrm{~mL})$. The organic phases were combined and dried over $\mathrm{Na}_{2} \mathrm{SO}_{4}$, filtered, and concentrated under reduced pressure. The residue (obtained as a colourless oil) was purified by FCC (3:2 EtOAc-petroleum ether, $R_{\mathrm{f}} 0.66$ ) to afford the 6 '-tosyl derivative $(2.4 \mathrm{~g}, 92 \%)$ as a colourless oil.

Sodium azide $(0.29 \mathrm{~g}, 4.65 \mathrm{mmol})$ was added to a solution of $3(2.1 \mathrm{~g}, 3.1 \mathrm{mmol})$ in dimethyl sulfoxide $(20 \mathrm{~mL})$ and the resulting mixture was heated at $90^{\circ} \mathrm{C}$ for $20 \mathrm{~h}$. The mixture was cooled, filtered, and the filtrate was diluted with water $(50 \mathrm{~mL})$ and extracted with $\mathrm{CH}_{3} \mathrm{Cl}(4 \times 30 \mathrm{~mL})$. The organic phases were combined, dried over $\mathrm{Na}_{2} \mathrm{SO}_{4}$, and concentrated in vacuo. The residue (obtained as a colourless oil) was purified by FCC eluting with 2:1 EtOAc-petroleum ether to afford the $6^{\prime}$-azido derivative $(1.5 \mathrm{~g}, 91 \%)$ as a colourless oil, $R_{\mathrm{f}} 0.54,2: 1$ EtOAc-petroleum ether).

A solution of the prepared azido derivative $(1.5 \mathrm{~g}, 2.8 \mathrm{mmol})$ in $\mathrm{CH}_{3} \mathrm{OH}(25 \mathrm{~mL})$ was hydrogenated in presence of $10 \%$ palladium on carbon $(200 \mathrm{mg}$ ) for $20 \mathrm{~h}$ at room temperature. The solution was filtered through a pad of Celite ${ }^{\circledR}$ and the filtrate was concentrated under reduced pressure. The residue was purified by precipitation from ether at $0{ }^{\circ} \mathrm{C}$ to afford $\mathbf{4}(1.36 \mathrm{~g}, 96 \%)$ as a light yellow powder having NMR data and physico-chemical properties identical with those of an authentic sample. ${ }^{4}$

\subsection{Ethyl 2-\{4-[2-methoxy-4-(4'-nitrophenylazo)phenylazo] phenoxy\}acetate (1b)}

Disperse dye 1a (1.5 g, $3.97 \mathrm{mmol})$ was added to a solution of $\mathrm{KOH}$ (1.12 g, $19.89 \mathrm{mmol})$ in THF (15 mL) and the resulting mixture was stirred at room temperature for $1.5 \mathrm{~h}$. Ethyl 2-bromoacetate $(1.32 \mathrm{~mL}, 11.91 \mathrm{mmol})$ and catalytic quantity of 18 -crown-6 were added and the resulting solution was stirred at room temperature for $20 \mathrm{~h}$. The reaction mixture was filtered, the filtrate was diluted with water $(40 \mathrm{~mL})$ and extracted with $\mathrm{CH}_{3} \mathrm{Cl}(4 \times 30 \mathrm{~mL})$. The organic phase was dried over $\mathrm{Na}_{2} \mathrm{SO}_{4}$, filtered, and the filtrate was concentrated under reduced pressure. Purification by FCC eluting with 4:9 EtOAc-petroleum ether afforded $\mathbf{1 b}(1.67 \mathrm{~g}, 91 \%)$ as an orange solid, $R_{\mathrm{f}} 0.75$ (4:9 EtOAc-petroleum ether), $\mathrm{mp} 158-160{ }^{\circ} \mathrm{C}$ (chrom). ${ }^{1} \mathrm{H}$ NMR (200 MHz, $\left.\mathrm{CDCl}_{3}\right): \delta 8.44(\mathrm{~m}, 2 \mathrm{H}, \mathrm{ArH}) ; 8.16-7.91(\mathrm{~m}, 4 \mathrm{H}$, ArH), 7.88-7.76 (m, 3H, ArH), $7.01(\mathrm{~m}, 2 \mathrm{H} . \mathrm{ArH}), 4.95\left(\mathrm{~s}, 2 \mathrm{H}, \mathrm{OCH}_{2-}\right.$ CO), 4.11 (q, $\left.2 \mathrm{H}, J=7.1 \mathrm{~Hz}, \mathrm{CH}_{2} \mathrm{CH}_{3}\right), 3.77\left(\mathrm{~s}, 3 \mathrm{H}, \mathrm{PhOCH}_{3}\right), 1.33$ (t, $\left.3 \mathrm{H}, J=7.1 \mathrm{~Hz}, \mathrm{CH}_{2} \mathrm{CH}_{3}\right) .{ }^{13} \mathrm{C} \mathrm{NMR}\left(50 \mathrm{MHz}, \mathrm{CDCl}_{3}\right): \delta 169.74(\mathrm{CO})$, $159.75,157.02,155.67,153.97,148.80,147.57,144.71,125.37$, $124.76,123.55,118.83,117.68,115.81,114.78(\mathrm{ArC}), 66.12\left(\mathrm{OCH}_{2-}\right.$ CO), $61.22\left(\mathrm{CH}_{2} \mathrm{CH}_{3}\right), 53.88\left(\mathrm{PhOCH}_{3}\right), 14.16\left(\mathrm{CH}_{2} \mathrm{CH}_{3}\right)$. MS (ESI) m/ $z=464.28[\mathrm{M}+1]^{+}$. Anal. Calcd for $\mathrm{C}_{23} \mathrm{H}_{21} \mathrm{~N}_{5} \mathrm{O}_{6}$ (463.15): C, 59.61; H, 4.57; N, 15.11. Found: C, 59.55; H, 4.48; N, 15.21 .

\subsection{2-\{4-[2'-Methoxy-4-(p-nitrophenylazo)phenylazo] phenoxy\}acetic acid (1c)}

$\mathrm{KOH}(0.54 \mathrm{~g}, 9.69 \mathrm{mmol})$ was added to a solution of $\mathbf{1 b}(1.5 \mathrm{~g}$, $3.23 \mathrm{mmol})$ in $1: 1 \mathrm{THF}-\mathrm{H}_{2} \mathrm{O}(16 \mathrm{~mL})$ and the resulting mixture was stirred at room temperature for $2 \mathrm{~h}$. The TLC indicated the disappearance of the starting product $\mathbf{1} \mathbf{b}\left(R_{\mathrm{f}} 0.86\right.$, EtOAc) and the formation of one major spot $\left(R_{\mathrm{f}} 0.1\right)$. The solution was diluted with water $(25 \mathrm{~mL})$ and extracted with $\mathrm{CH}_{3} \mathrm{Cl}(3 \times 20 \mathrm{~mL})$. The aqueous solution was acidified with $1 \mathrm{~N} \mathrm{HCl}$ to $\mathrm{pH} 2$ and extracted with EtOAc $(30 \mathrm{~mL})$. The organic solution was dried over $\mathrm{Na}_{2} \mathrm{SO}_{4}$ and filtered, the

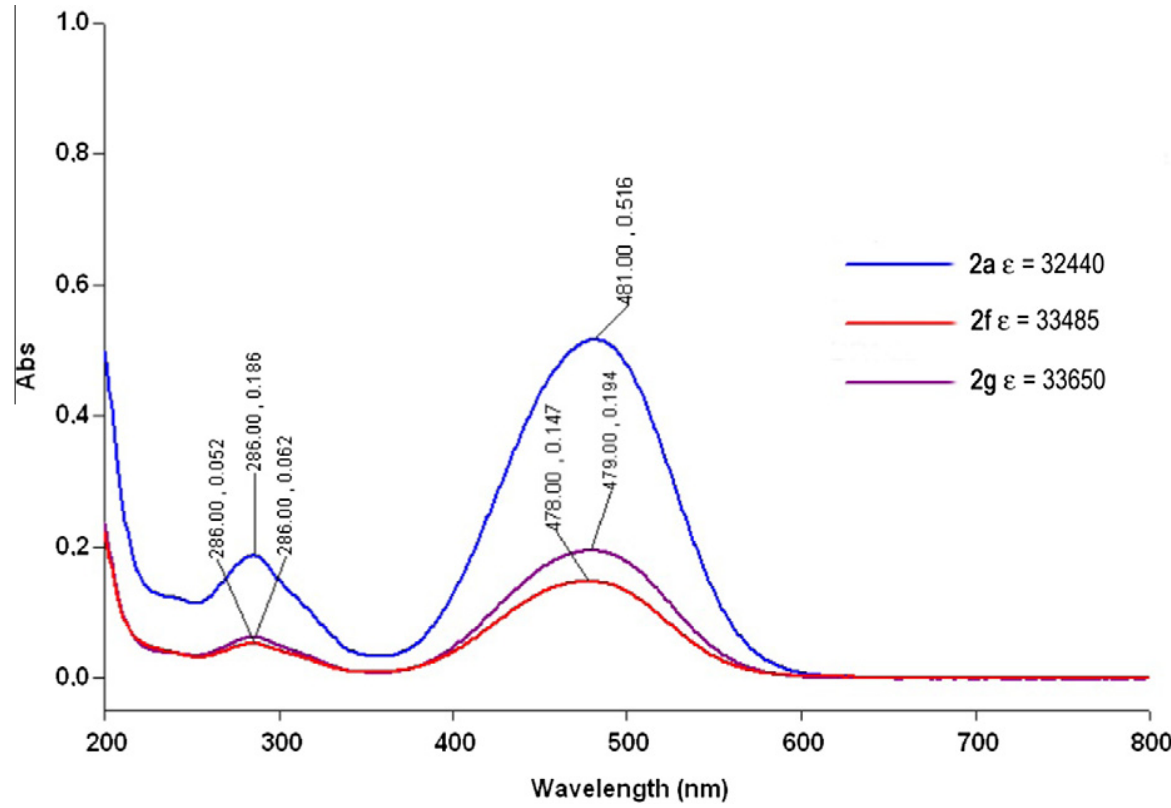

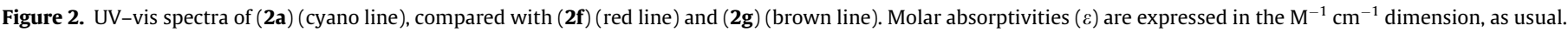


solvent was removed under reduced pressure to afford $\mathbf{1 c}(1.37 \mathrm{~g}$, $98 \%)$ as a red solid, $\mathrm{mp} 238-240{ }^{\circ} \mathrm{C} .{ }^{1} \mathrm{H}$ NMR $\left(200 \mathrm{MHz}, \mathrm{CDCl}_{3}\right): \delta$ 8.41 (m, 2H, ArH); 8.15-7.91 (m, 4H, ArH), 7.87-7.76 (m, 3H, ArH), $7.02(\mathrm{~m}, 2 \mathrm{H} . \mathrm{ArH}), 4.84\left(\mathrm{~s}, 2 \mathrm{H}, \mathrm{OCH}_{2} \mathrm{CO}\right), 3.76\left(\mathrm{~s}, 3 \mathrm{H}, \mathrm{PhOCH}_{3}\right) .{ }^{13} \mathrm{C}$ NMR $\left(50 \mathrm{MHz}, \mathrm{CDCl}_{3}\right): \delta 162.74(\mathrm{CO}), 159.77,157.08,155.67$, 153.97, 148.80, 147.57, 144.71, 125.37, 124.74, 123.56, 118.83, 117.67, 115.82, $114.78(\mathrm{ArCH}), 66.98\left(\mathrm{OCH}_{2} \mathrm{CO}\right), 53.88\left(\mathrm{PhOCH}_{3}\right)$. MS (ESI) $m / z=436.11[\mathrm{M}+1]^{+}$. Anal. Calcd for $\mathrm{C}_{21} \mathrm{H}_{17} \mathrm{~N}_{5} \mathrm{O}_{6}$ (435.12): C, 57.93; H, 3.94; N, 16.09. Found: C, 57.88; H, 3.87; N, 16.32 .

\subsection{2 - $\{4-[2$ '-Methoxy-4-(p-nitrophenylazo)phenylazo] phenoxy\}-acetyl-(diethyl ester)-1' -glutamic amide (1d)}

Triethylamine ( $1.64 \mathrm{~mL}, 11.73 \mathrm{mmol})$ was added to a solution of 1c $(1.70 \mathrm{~g}, 3.90 \mathrm{mmol})$ in THF $(15 \mathrm{~mL})$ and the mixture stirred at room temperature for $5 \mathrm{~min}$. To the resulting solution, cooled to $0{ }^{\circ} \mathrm{C}$, ethyl chloroformate $(1.13 \mathrm{~mL}, 11.73 \mathrm{mmol})$ was added, and the mixture was stirred at $0{ }^{\circ} \mathrm{C}$ for $30 \mathrm{~min}$ until TLC indicated the formation of the activated intermediate $\left(R_{\mathrm{f}} 0.72\right.$, EtOAc-petroleum ether) and the disappearance of the starting acid $\left(R_{\mathrm{f}} 0.1\right)$. Diethyl Lglutamate hydrochloride $(0.94 \mathrm{~g}, 3.91 \mathrm{mmol})$ was then added, followed immediately by triethylamine $(0.54 \mathrm{~mL}, 3.91 \mathrm{mmol})$. The reaction mixture was stirred at room temperature overnight, then was again cooled to $0{ }^{\circ} \mathrm{C}$ and subjected to another cycle of activation and coupling using half the quantities listed above. The reaction mixture was slowly allowed to warm to room temperature and stirred for additional $24 \mathrm{~h}$. TLC showed the formation of one major spot $\left(R_{\mathrm{f}}=0.44\right.$, EtOAc-petroleum ether $\left.3: 1\right)$. The solvent was evaporated under reduced pressure and the residue was purified by FCC on silica gel, eluting with EtOAc-petroleum ether $3: 1$ $\left(R_{\mathrm{f}}=0.44\right)$ to afford $1 \mathrm{~d}(2.18 \mathrm{~g}, 90 \%)$ as a red amorphous foam, mp $185-187^{\circ} \mathrm{C}$ (chrom). ${ }^{1} \mathrm{H}$ NMR $\left(200 \mathrm{MHz}, \mathrm{CDCl}_{3}\right): \delta 8.41(\mathrm{~m}$, $2 \mathrm{H}, \mathrm{ArH}) ; 8.15-7.91(\mathrm{~m}, 4 \mathrm{H}, \mathrm{ArH}), 7.87-7.76(\mathrm{~m}, 3 \mathrm{H}, \mathrm{ArH}), 7.02$ $(\mathrm{m}, 2 \mathrm{H} . \mathrm{ArH}), 4.84-4.54\left(\mathrm{~m}, 3 \mathrm{H}, \mathrm{OCH}_{2} \mathrm{CO}, \mathrm{CH}\right), 4.14(\mathrm{q}, 2 \mathrm{H}$, $\left.J=7.0 \mathrm{~Hz}, \quad \mathrm{CH}_{2} \mathrm{CH}_{3}\right), \quad 3.76\left(\mathrm{~s}, 3 \mathrm{H}, \mathrm{PhOCH}_{3}\right), 2.29(\mathrm{~m}, 4 \mathrm{H}$, $\left.\mathrm{CHCH}_{2} \mathrm{CH}_{2} \mathrm{CO}\right), 1.32\left(\mathrm{t}, 6 \mathrm{H}, J=7.0 \mathrm{~Hz}, 2 \times \mathrm{CH}_{2} \mathrm{CH}_{3}\right) .{ }^{13} \mathrm{C} \mathrm{NMR}$ $\left(50 \mathrm{MHz}, \mathrm{CDCl}_{3}\right): \delta 171.54,171.11,162.74(3 \times \mathrm{CO}), 159.77$, $157.08,155.67,153.97,148.80,147.57,144.71,125.37,124.74$, $123.56,118.83,117.67,115.82,114.78(\mathrm{ArCH}), 67.48\left(\mathrm{OCH}_{2} \mathrm{CO}\right)$, $61.24\left(2 \times \mathrm{CH}_{2} \mathrm{CH}_{3}\right), 53.57\left(\mathrm{PHOCH}_{3}\right), 51.24(\mathrm{CH}), 28.54,27.11$ $\left(\mathrm{CHCH}_{2} \mathrm{CH}_{2} \mathrm{CO}\right), 14.21\left(2 \times \mathrm{CH}_{3}\right)$. Ms (ESI) $\mathrm{m} / \mathrm{z}=621.39[\mathrm{M}+1]^{+}$. Anal. Calcd for $\mathrm{C}_{30} \mathrm{H}_{32} \mathrm{~N}_{6} \mathrm{O}_{9}$ (620.22): C, 58.06; H, 5.20; N, 13.54 . Found: C, 57.98; H, 5.14; N, 13.60 .

\subsection{2-\{4-[2'-Methoxy-4-(p-nitrophenylazo)phenylazo] phenoxy\}-acetyl-1'-glutamic acid (1e)}

$\mathrm{KOH}(0.54,9.67 \mathrm{mmol})$ was added to a solution of the diester $1 \mathrm{~d}$ $(2 \mathrm{~g}, 3.22 \mathrm{mmol})$ in $\mathrm{H}_{2} \mathrm{O}-\mathrm{THF} 1: 1(20 \mathrm{~mL})$ and the mixture was stirred at room temperature for $20 \mathrm{~h}$. TLC showed the disappearance of the starting material (EtOAc, $R_{\mathrm{f}}=0.83$ ) and formation of one major spot at the baseline. The reaction mixture was evaporated to dryness under reduced pressure and the residue dissolved in water $(20 \mathrm{~mL})$. The resulting solution was cooled in an ice bath and the $\mathrm{pH}$ adjusted to 2 by dropwise addition of $1 \mathrm{~N} \mathrm{HCl}$. The resulting suspension was extracted with $\mathrm{CH}_{3} \mathrm{Cl}(20 \mathrm{~mL})$ and the organic phase was dried over $\mathrm{Na}_{2} \mathrm{SO}_{4}$, filtered, and evaporated under reduced pressure to afford $1 \mathrm{e}(1.78 \mathrm{~g}, 98 \%)$ as a black powder, $\mathrm{mp}$ $271-275^{\circ} \mathrm{C}(\mathrm{dec})$. 1e is soluble in water at $\mathrm{pH}>7 .{ }^{1} \mathrm{H}$ NMR $\left(200 \mathrm{MHz}, \mathrm{CDCl}_{3}\right): \delta 8.40(\mathrm{~m}, 2 \mathrm{H}, \mathrm{ArH}) ; 8.15-7.91(\mathrm{~m}, 4 \mathrm{H}, \mathrm{ArH})$, 7.88-7.78 (m, 3H, ArH), $7.01(\mathrm{~m}, 2 \mathrm{H} . \mathrm{ArH}), 4.87-4.51\left(\mathrm{~m}, 3 \mathrm{H}, \mathrm{OCH}_{2-}\right.$ $\mathrm{CO}, \mathrm{CH}), 3.74\left(\mathrm{~s}, 3 \mathrm{H}, \mathrm{PhOCH}_{3}\right), 2.29-2.07\left(\mathrm{~m}, 4 \mathrm{H}, \mathrm{CHCH}_{2}, \mathrm{CH}_{2} \mathrm{CO}\right)$. ${ }^{13} \mathrm{C}$ NMR $\left(50 \mathrm{MHz}, \mathrm{CDCl}_{3}\right): \delta$ 176.97, $174.54(2 \times \mathrm{CO}), 162.55$ (CO), 159.77, 157.08, 155.67, 153.97, 148.80, 147.57, 144.71, 125.37, 124.74, 123.56, 118.83, 117.67, 115.82, $114.78(\mathrm{ArCH})$, $67.48\left(\mathrm{OCH}_{2} \mathrm{CO}\right), 53.54\left(\mathrm{PhOCH}_{3}\right) . \mathrm{MS}(\mathrm{ESI}) \mathrm{m} / z=565.21[\mathrm{M}+1]^{+}$.
Anal. Calcd for $\mathrm{C}_{26} \mathrm{H}_{24} \mathrm{~N}_{6} \mathrm{O}_{9}$ (564.16): C, 55.32; H, 4.29; N, 14.89 . Found: C, 55.22; H, 4.18; N, 15.12 .

\subsection{2-\{4-[2'-Methoxy-4-(p-nitrophenylazo)phenylazo] phenoxy\}-acetyl-1'-glutamic-bis-\{4-0-[6-0-amino-6-deoxy-3,4- $O$-(isopropylidene)- $\beta$-D-galactopyranosyl]-2,3:5,6-di-O- isopropylidene-aldehydo-D-glucose dimethyl acetal\}amide (1f)}

$\mathrm{N}$-Methyl morpholine (NMO, $0.88 \mathrm{~mL}, 7.98 \mathrm{mmol}$ ) was added to a solution of $1 \mathbf{e}(1.5 \mathrm{~g}, 2.66 \mathrm{mmol})$ in THF $(15 \mathrm{~mL})$ and the mixture was stirred at room temperature for $5 \mathrm{~min}$. The resulting solution was cooled to $0{ }^{\circ} \mathrm{C}$, 2-chloro-4,6-dimethoxy-1,3,5-triazine ( $1.34 \mathrm{~g}, 7.98 \mathrm{mmol}$ ) was added and the mixture was stirred at room temperature. After $2 \mathrm{~h}$, TLC indicated the formation of the activated intermediate $\left(R_{\mathrm{f}}=0.77, \mathrm{CH}_{2} \mathrm{Cl}_{2}-\mathrm{CH}_{3} \mathrm{OH} \mathrm{10:0.5)}\right.$ and the disappearance of the starting acid $\left(R_{\mathrm{f}}=0.1\right)$. Amino lactose $4(2.70 \mathrm{~g}$, $5.32 \mathrm{mmol}$ ) was added and the reaction mixture was stirred at room temperature for $24 \mathrm{~h}$ when TLC showed the formation of one major spot at $\left(R_{\mathrm{f}}=0.39, \mathrm{CH}_{2} \mathrm{Cl}_{2}-\mathrm{CH}_{3} \mathrm{OH} 10: 0.5\right)$. The reaction mixture was evaporated to dryness under reduced pressure and the residue was dissolved in $\mathrm{CH}_{3} \mathrm{Cl}(20 \mathrm{~mL})$ and washed with $5 \%$ $\mathrm{HCl}(20 \mathrm{~mL})$ and water $(3 \times 20 \mathrm{~mL})$. The organic solution was dried over $\mathrm{Na}_{2} \mathrm{SO}_{4}$ and filtered, the filtrate was concentrated under reduced pressure and the residue was purified by FCC eluting with $\mathrm{CH}_{2} \mathrm{Cl}_{2}-\mathrm{CH}_{3} \mathrm{OH} 10: 0.4\left(R_{\mathrm{f}}=0.35\right)$ to afford $\mathbf{1 f}(3.73 \mathrm{~g}, 91 \%)$ as a red foam, mp $143-146{ }^{\circ} \mathrm{C}$ (chrom). ${ }^{1} \mathrm{H}$ NMR (200 MHz, $\left.\mathrm{CDCl}_{3}\right): \delta$ 8.43-8.38 (m, 2H, ArH); 8.12-7.89 (m, 4H, ArH), 7.79-7.63 (m, $3 \mathrm{H}, \mathrm{ArH}), 7.03-6.97(\mathrm{~m}, 2 \mathrm{H}$. ArH), 4.87-4.51 (m, 7H), 4.38-4.35 $(\mathrm{m}, 2 \mathrm{H}), 4.28-4.24(\mathrm{~m}, 3 \mathrm{H}) 4.15-3.94(\mathrm{~m}, 12 \mathrm{H}), 3.74-3.49(\mathrm{~m}$, $14 \mathrm{H}), 3.44-3.41\left(\mathrm{~s}, 12 \mathrm{H}, 4 \times \mathrm{OCH}_{3}\right), 2.30-2.11\left(\mathrm{~m}, 4 \mathrm{H}, \mathrm{CHCH}_{2}\right.$ $\mathrm{CH}_{2} \mathrm{CO}$ ), $1.60-1.20$ (various overlapping signals, $36 \mathrm{H}$ ). ${ }^{13} \mathrm{C} \mathrm{NMR}$ $\left(50 \mathrm{MHz}, \mathrm{CDCl}_{3}\right): \delta 174.87,173.64(2 \times \mathrm{CO}), 162.33$ (CO), 159.77, $157.08,155.67,153.97,148.80,147.57,144.71,125.37,124.74$ 123.56, 118.83, 117.67, 115.82, $114.78(\mathrm{ArCH}), 110.44,109.57$, $108.12\left[\mathrm{C}\left(\mathrm{CH}_{3}\right)_{2}\right], 67.48\left(\mathrm{OCH}_{2} \mathrm{CO}\right), 53.54\left(\mathrm{PhOCH}_{3}\right), 51.77(\mathrm{CH})$, $29.11,28.81,27.66,26.84,26.44,25.68,25.25,24.47$. Glycidic signals were also at 106.1, 103.5, 79.0, 78.0, 76.3, 76.6, 74.2, 72.6, 71.3, 70.7, 64.7, 40.3. UV-vis $\lambda_{\max }=417 \mathrm{~nm}$. MS (ESI) $m / z=1543.11$ $[\mathrm{M}]^{+}$. Anal. Calcd for $\mathrm{C}_{72} \mathrm{H}_{102} \mathrm{~N}_{8} \mathrm{O}_{29}$ (1543.62): C, 56.02; $\mathrm{H}, 6.66 ; \mathrm{N}$ 7.26. Found: C, 56.47; H, 6.69; N, 7.50.

\subsection{2-\{4-[2'-Methoxy-4-(p-nitrophenylazo)phenylazo] phenoxy\}-acetyl-1'-glutamic-bis-(6'-amino-lactose)amide (1g)}

A solution of $\mathbf{1 f}(2.0 \mathrm{~g}, 1.29 \mathrm{mmol})$ in $90 \%$ aqueous $\mathrm{CF}_{3} \mathrm{COOH}$ $(15 \mathrm{~mL})$ was stirred at room temperature overnight. The TLC indicated the disappearance of starting material $\left(R_{\mathrm{f}}=0.33, \mathrm{CH}_{2} \mathrm{Cl}_{2}-\right.$ $\left.\mathrm{CH}_{3} \mathrm{OH} 10: 0.5\right)$ and the formation of compound $1 \mathrm{~g}\left(R_{\mathrm{f}}=0.1\right)$. The violet solution was evaporated to dryness and repeatedly coevaporated with toluene $(5 \times 25 \mathrm{~mL})$ at reduced pressure to give the final product $1 \mathrm{~g}(1.59 \mathrm{~g}, 99 \%)$ as red powder, mp $201-204{ }^{\circ} \mathrm{C} .{ }^{1} \mathrm{H}$ NMR (200 MHz, $\left.\mathrm{D}_{2} \mathrm{O}\right): \delta 8.35-8.29(\mathrm{~m}, 2 \mathrm{H}, \mathrm{ArH}$, both anomers); 8.18-7.89 ( $\mathrm{m}, 4 \mathrm{H}, \mathrm{ArH}$, both anomers), 7.81-7.64 (m, 3H, ArH, both anomers), 7.74-7.68 (m, 2H, ArH, both anomers), 5.08-4.57 (m, 7H both anomers) $4.24-4.17(\mathrm{~m}, 8 \mathrm{H}$, both anomers) $3.91-3.81(\mathrm{~m}$, $12 \mathrm{H}$, both anomers), $3.74\left(\mathrm{~s}, 3 \mathrm{H}, \mathrm{PhOCH}_{3}\right.$ both anomers), 3.43$3.40\left(\mathrm{~m}, 4 \mathrm{H}\right.$, both anomers) $2.29-2.07\left(\mathrm{~m}, 4 \mathrm{H}, \mathrm{CHCH}_{2}, \mathrm{CH}_{2} \mathrm{CO}\right)$. ${ }^{13} \mathrm{C}$ NMR $\left(50 \mathrm{MHz}, \mathrm{D}_{2} \mathrm{O}\right): \delta 176.97-173.54(2 \times \mathrm{CO}), 162.55(\mathrm{CO})$, $159.77,157.08,155.67,153.97,148.80,147.57,144.71,125.37$ $124.74,123.56,118.83,117.67,115.82,114.78(\mathrm{ArCH}), 67.48$ $\left(\mathrm{OCH}_{2} \mathrm{CO}\right), 53.54\left(\mathrm{PhOCH}_{3}\right), 51.77(\mathrm{CH}), 29.11-26.87\left(\mathrm{CHCH}_{2}\right.$ $\mathrm{CH}_{2} \mathrm{CO}$ ) other signals for glycidic moiety : 103.7, 79.6, 78.4, 74.1, $71.9, \quad 61.5, \quad 106.6,74.4,77.8,73.5,77.6,64.5$ ). MS (ESI) $\mathrm{m} /$ $z=1210.31[\mathrm{M}]^{+}$Anal. Calcd for $\mathrm{C}_{50} \mathrm{H}_{66} \mathrm{~N}_{8} \mathrm{O}_{27}$ (1210.40): C, 49.59; H, 5.49; N, 9.25. Found: C, 49.44; H, 5.41; N, 9.39. 
1.9. $N$-Ethyl- $N$-(2-(acetylacetoxy)ethyl)-4-(4' -nitrophenylazo) aniline (2b)

To a solution of disperse dye $2 \mathbf{a}(1.2 \mathrm{~g}, 3.8 \mathrm{mmol})$ in THF $(24 \mathrm{~mL}), \mathrm{NaH}(60 \%$ disperse in mineral oil, $352 \mathrm{mg}, 8.8 \mathrm{mmol})$ was added at room temperature. After $8 \mathrm{~h}$, ethyl 2-bromoacetate $(1.1 \mathrm{ml}, 9.9 \mathrm{mmol})$ was added dropwise and the reaction mixture was stirred overnight and then carefully quenched with $1: 1$ saturated $\mathrm{NH}_{4} \mathrm{Cl}-\mathrm{H}_{2} \mathrm{O}(50 \mathrm{~mL})$ at $0{ }^{\circ} \mathrm{C}$. The whole was extracted with EtOAc $(50 \mathrm{~mL})$, the organic phase was separated, washed with brine $(50 \mathrm{~mL})$, and dried over $\mathrm{Na}_{2} \mathrm{SO}_{4}$. The suspension was filtered under reduced pressure and the filtrate was evaporated to dryness. The residue was purified by FCC, eluting with 98:2 $\mathrm{CH}_{2} \mathrm{Cl}_{2}$-EtOAc to afford $\mathbf{2 b}$ as a red amorphous solid $(1.1 \mathrm{~g}, 72 \%), R_{\mathrm{f}} 0.55(98: 2$ $\mathrm{CH}_{2} \mathrm{Cl}_{2}$-EtOAc), mp 86-88 ${ }^{\circ} \mathrm{C}$ (chrom). ${ }^{1} \mathrm{H}$ NMR (200 MHz, $\mathrm{CDCl}_{3}$ ): $\delta$ 8.32-8.30 (m, 2H, 3'-H, 5'-H), 7.92-7.87 (m, 4H, 2'-H, 6'-H, 3-H, 5-H), 6.79-6.76 (m, 2H, 2-H, 6-H), $4.22\left(\mathrm{q}, 2 \mathrm{H}, J=7.2 \mathrm{~Hz}, \mathrm{CH}_{2} \mathrm{CH}_{3}\right)$, $4.11\left(\mathrm{~s}, 2 \mathrm{H}, \mathrm{OCH}_{2} \mathrm{CO}\right), 3.78\left(\mathrm{t}, 2 \mathrm{H}, J=5.8 \mathrm{~Hz}, \mathrm{OCH}_{2} \mathrm{CH}_{2} \mathrm{~N}\right), 3.69(\mathrm{t}, 2 \mathrm{H}$, $\left.J=5.8 \mathrm{~Hz}, \mathrm{OCH}_{2} \mathrm{CH}_{2} \mathrm{~N}\right) 3.57\left(\mathrm{q}, 2 \mathrm{H}, J=7.2 \mathrm{~Hz}, \mathrm{NCH}_{2} \mathrm{CH}_{3}\right), 1.30-1.24$ (m $\left.6 \mathrm{H}, \mathrm{NCH}_{2} \mathrm{CH}_{3}, \mathrm{CH}_{2} \mathrm{CH}_{3}\right) .{ }^{13} \mathrm{C}$ NMR $\left(50 \mathrm{MHz}, \mathrm{CDCl}_{3}\right): \delta 170.1$ (CO), 156.8, 151.4, 147.3, 143.6, 126.2, 124.6, 122.5, $111.3(\operatorname{ArC})$ $69.0\left(\mathrm{OCH}_{2} \mathrm{CO}\right), 68.7\left(\mathrm{OCH}_{2} \mathrm{CH}_{3} \mathrm{~N}\right), 61.0\left(\mathrm{NCH}_{2} \mathrm{CH}_{3}\right), 50.1,46.0$, $14.2\left(\mathrm{CH}_{2} \mathrm{CH}_{3}\right), 12.2\left(\mathrm{NCH}_{2} \mathrm{CH}_{3}\right)$. MS (ESI) $\mathrm{m} / z=401.11[\mathrm{M}+1]^{+}$. Anal. Calcd for $\mathrm{C}_{20} \mathrm{H}_{24} \mathrm{~N}_{4} \mathrm{O}_{5}(400.20)$ : C, 59.99; H, 6.04; N, 13.99. Found: C, 59.87; H, 5.97; N, 14.08

\subsection{0. $N$-Ethyl- $N$-(2-(2'-hydrocarboxy)ethyloxy)-4-(4-nitrophe- nylazo)aniline (2c)}

$\mathrm{KOH}(0.55 \mathrm{~g}, 9.8 \mathrm{mmol})$ was added to a solution of $\mathbf{2 b}(1.96 \mathrm{~g}$, $4.9 \mathrm{mmol})$ in $1: 1 \mathrm{THF}-\mathrm{H}_{2} \mathrm{O}(16 \mathrm{~mL})$ and the resulting mixture was stirred at room temperature for $2 \mathrm{~h}$. The TLC indicated the disappearance of the starting product (EtOAc-petroleum ether 3:7, $\left.R_{\mathrm{f}}=0.66\right)$ and the formation of a major spot $\left(R_{\mathrm{f}}=0.1\right)$. The solution was diluted with water $(25 \mathrm{~mL})$ and extracted with $\mathrm{CH}_{3} \mathrm{Cl}$ $(3 \times 20 \mathrm{~mL})$. The aqueous solution was acidified with $1 \mathrm{~N} \mathrm{HCl}$ to pH 2 and extracted with $\mathrm{CH}_{3} \mathrm{Cl}(30 \mathrm{~mL})$. The organic phase was dried over $\mathrm{Na}_{2} \mathrm{SO}_{4}$, filtered, and concentrated under reduced pressure to afford $2 \mathrm{c}(1.54 \mathrm{~g}, 84 \%)$ as a red solid, $\mathrm{mp} 159-162{ }^{\circ} \mathrm{C}$. $2 \mathrm{c}$ is soluble in water at $\mathrm{pH}>7 .{ }^{1} \mathrm{H}$ NMR $\left(200 \mathrm{MHz}\right.$, acetone- $\left.d_{6}\right): \delta 8.32$ $7.92\left(\mathrm{~m}, 4 \mathrm{H}, 2^{\prime}-\mathrm{H}, 3^{\prime} \mathrm{H}, 5^{\prime} \mathrm{H}, 6^{\prime} \mathrm{H}\right), 7.90-6.79\left(\mathrm{~m}, 4 \mathrm{H}, 8^{\prime} \mathrm{H}, 9^{\prime} \mathrm{H}, 11^{\prime} \mathrm{H}\right.$, $\left.12^{\prime} \mathrm{H}\right), 4.31\left(\mathrm{~s}, 2 \mathrm{H}, \mathrm{OCH}_{2} \mathrm{CO}\right), 3.71-3.26\left(\mathrm{~m}, 6 \mathrm{H}, 3 \times \mathrm{NCH}_{2}-\right), 1.14$ $\left(\mathrm{t}, 3 \mathrm{H}, J=7.1 \mathrm{~Hz}, \mathrm{CH}_{2} \mathrm{CH}_{3}\right) .{ }^{13} \mathrm{C} \mathrm{NMR}\left(50 \mathrm{MHz}\right.$, acetone- $\left.d_{6}\right): \delta$ 168.87 (CO), 156.60, 151.10, 147.3, 143.7, 126.2, 124.6, 122.6, $111.3(\mathrm{ArC}) 66.47,\left(\mathrm{OCH}_{2} \mathrm{CO}\right), 61.5\left(\mathrm{NCH}_{2} \mathrm{CH}_{3}\right), 48.7,45.7\left(\mathrm{NCH}_{2} \mathrm{CH}_{2}\right.$, $\left.\mathrm{NCH}_{2} \mathrm{CH}_{3}\right), 12.2\left(\mathrm{NCH}_{2} \mathrm{CH}_{3}\right)$. MS (ESI) $m / z=373.35[\mathrm{M}+1]^{+}$. Anal. Calcd for $\mathrm{C}_{18} \mathrm{H}_{20} \mathrm{~N}_{4} \mathrm{O}_{5}$ (372.21): C, 58.06; H, 5.41; N, 15.05. Found: C, $58.01 ; \mathrm{H}, 5.34 ; \mathrm{N}, 15.12$.

\subsection{1. $N$-Ethyl- $N$-(2-(2'-carboxyglutamic(diethyl ester)-1' -amido)} ethyloxy)-4-(4-nitrophenylazo)aniline (2d)

Thionyl chloride $(0.24 \mathrm{~mL}, 3.3 \mathrm{mmol})$ was added to a solution of 2c $(1.12 \mathrm{~g}, 3.0 \mathrm{mmol})$ in $\mathrm{CH}_{2} \mathrm{Cl}_{2}(12 \mathrm{~mL})$ at $0{ }^{\circ} \mathrm{C}$. The whole was stirred at $0{ }^{\circ} \mathrm{C}$ for $1.5 \mathrm{~h}$ and then at room temperature for $3 \mathrm{~h}$. The dark red solution was thereafter added dropwise to an ice precooled solution of L-glutamic acid diethyl ester hydrochloride $(0.7 \mathrm{~g}$, $3.0 \mathrm{mmol}$ ) and TEA (2.1 mL, $15.1 \mathrm{mmol})$ in $\mathrm{CH}_{2} \mathrm{Cl}_{2}(12 \mathrm{~mL})$. Stirring was continued for $2 \mathrm{~h}$ at $0{ }^{\circ} \mathrm{C}$ and then at room temperature overnight. The mixture was diluted with $\mathrm{CH}_{2} \mathrm{Cl}_{2}(24 \mathrm{~mL})$ and washed with $\mathrm{H}_{2} \mathrm{O}(2 \times 50 \mathrm{~mL})$. The organic phase was separated, dried over $\mathrm{Na}_{2} \mathrm{SO}_{4}$, and the resulting suspension filtered under reduced pressure. The filtrate was collected and evaporated to dryness to afford 2d as a crude red solid ( $1.5 \mathrm{~g}, 90 \%)$ which was used without further purification for the next step. ${ }^{1} \mathrm{H}$ NMR $\left(200 \mathrm{MHz}, \mathrm{CDCl}_{3}\right): \delta 8.32-$ $7.92\left(\mathrm{~m}, 4 \mathrm{H}, 2^{\prime}-\mathrm{H}, 3^{\prime} \mathrm{H}, 5^{\prime} \mathrm{H}, 6^{\prime} \mathrm{H}\right), 7.90-6.79\left(\mathrm{~m}, 4 \mathrm{H}, 8^{\prime} \mathrm{H}, 9^{\prime} \mathrm{H}, 11^{\prime} \mathrm{H}\right.$, $\left.12^{\prime} \mathrm{H}\right), 4.44-4.38(\mathrm{~m}, 1 \mathrm{H}, \mathrm{CH}), 4.29-4.12\left(\mathrm{~m}, 6 \mathrm{H}, 2 \times \mathrm{CH}_{2} \mathrm{CH}_{3}, \mathrm{OCH}_{2-}\right.$ $\mathrm{CO})$, 3.69-3.24 (m, 6H, $\left.2 \times \mathrm{NCH}_{2} \mathrm{CH}_{2}, \mathrm{NCH}_{2} \mathrm{CH}_{3}\right), 2.32-2.25(\mathrm{~m}, 4 \mathrm{H}$, $\left.\mathrm{CHCH}_{2}, \mathrm{CH}_{2} \mathrm{CO}\right), 1.24-1.14\left(\mathrm{~m}, 9 \mathrm{H}, 2 \times \mathrm{CH}_{2} \mathrm{CH}_{3}, \mathrm{NCH}_{2} \mathrm{CH}_{3}\right) .{ }^{13} \mathrm{C} \mathrm{NMR}$ $\left(50 \mathrm{MHz}, \mathrm{CDCl}_{3}\right): \delta 171.19(2 \times \mathrm{CONH}), 168.87$ (CO), 156.60, $151.10,147.3,143.7,126.2,124.6,122.6,111.3(\mathrm{ArC}) 66.47,\left(\mathrm{OCH}_{2-}\right.$ $\mathrm{CO}), 61.57\left(\mathrm{CH}_{2} \mathrm{CH}_{3}\right), 61.47\left(\mathrm{NCH}_{2} \mathrm{CH}_{2}\right), 52.14(\mathrm{CH}), 48.77,45.67$ $\left(\mathrm{NCH}_{2} \mathrm{CH}_{2}, \quad \mathrm{NCH}_{2} \mathrm{CH}_{3}\right), \quad 28.47, \quad 26.25\left(\mathrm{CHCH}_{2}, \mathrm{CH}_{2} \mathrm{CO}\right), \quad 13.97$ $\left(\mathrm{CH}_{2} \mathrm{CH}_{3}\right), 12.2\left(\mathrm{NCH}_{2} \mathrm{CH}_{3}\right)$. MS (ESI) $\mathrm{m} / z=558.08[\mathrm{M}+1]^{+}$. Anal. Calcd for $\mathrm{C}_{27} \mathrm{H}_{35} \mathrm{~N}_{5} \mathrm{O}_{8}$ (557.21): C, 58.16; $\mathrm{H}, 6.33 ; \mathrm{N}, 12.56$. Found: C, 58.04; H, 6.18; N, 12.69 .

\subsection{2. $N$-Ethyl- $N$-(2-(2'-carboxyglutamic acid-1'-amido) ethyloxy)-4-(4-nitrophenyl-azo)aniline (2e)}

$\mathrm{KOH}(0.56 \mathrm{~g}, 10 \mathrm{mmol})$ was added to a solution of the diester $\mathbf{2 d}$ ( $1.4 \mathrm{~g}, 2.5 \mathrm{mmol}$ ) in $\mathrm{H}_{2} \mathrm{O}$-THF $1: 1$ (30 mL) and the mixture was stirred at room temperature overnight. TLC showed the disappearance of the starting material $\left(R_{\mathrm{f}}=0.35,2: 1\right.$ EtOAc-petroleum ether $)$ and the formation of a major spot at the baseline. The reaction mixture was evaporated to dryness under reduced pressure and the residue dissolved in water $(30 \mathrm{~mL})$. The resulting solution was cooled in an ice bath and the $\mathrm{pH}$ adjusted to 2 with dropwise addition of $1 \mathrm{~N} \mathrm{HCl}$. The resulting suspension was filtered and the cake was washed with $\mathrm{H}_{2} \mathrm{O}$ until $\mathrm{pH}$ neutral. Compound $2 \mathbf{e}$ was obtained, after drying in an oven at $60{ }^{\circ} \mathrm{C}$ overnight, as a red amorphous solid (1.2 g, 96\%), mp 186-190 (dec). ${ }^{1} \mathrm{H}$ NMR $\left(200 \mathrm{MHz}\right.$, acetone- $\left.d_{6}\right): \delta 8.32-7.92(\mathrm{~m}$, $\left.4 \mathrm{H}, 2^{\prime}-\mathrm{H}, 3^{\prime} \mathrm{H}, 5^{\prime} \mathrm{H}, 6^{\prime} \mathrm{H}\right), 7.90-6.79\left(\mathrm{~m}, 4 \mathrm{H}, 8^{\prime} \mathrm{H}, 9^{\prime} \mathrm{H}, 11^{\prime} \mathrm{H}, 12^{\prime} \mathrm{H}\right)$, $4.37(\mathrm{~m}, 1 \mathrm{H}, \mathrm{CH}), 4.29-4.13\left(\mathrm{~s}, 2 \mathrm{H}, \mathrm{OCH}_{2} \mathrm{CO}\right), 3.68-3.21(\mathrm{~m}, 6 \mathrm{H}$, $\mathrm{NCH}_{2} \mathrm{CH}_{2}, \mathrm{NCH}_{2} \mathrm{CH}_{3}, \mathrm{NCH}_{2} \mathrm{CH}_{2}$ ), 2.31-2.26 (m, 4H, $\mathrm{CHCH}_{2}, \mathrm{CH}_{2} \mathrm{CO}$ ), 1.24-1.14 (t, $\left.3 \mathrm{H}, J=7.1 \mathrm{~Hz}, \mathrm{CH}_{2} \mathrm{CH}_{3}\right) .{ }^{13} \mathrm{C}$ NMR $(50 \mathrm{MHz}$, acetone$\left.d_{6}\right): \delta 172.15(2 \mathrm{CONH}), 168.87(\mathrm{CO}), 156.65,151.17,147.35$, 143.74, 126.24, 124.65, 122.61, 111.31 (ArC) 66.51, (OCH2CO), $61.44\left(\mathrm{NCH}_{2} \mathrm{CH}_{2}\right), 52.55(\mathrm{CH}) 48.71,45.62\left(\mathrm{NCH}_{2} \mathrm{CH}_{2}, \mathrm{NCH}_{2} \mathrm{CH}_{3}\right)$, 28.46, 26.33, $\left(\mathrm{CHCH}_{2}, \mathrm{CH}_{2} \mathrm{CO}\right) 12.28\left(\mathrm{NCH}_{2} \mathrm{CH}_{3}\right)$. MS (ESI) m/ $z=502.32[\mathrm{M}+1]^{+}$. Anal. Calcd for $\mathrm{C}_{23} \mathrm{H}_{27} \mathrm{~N}_{5} \mathrm{O}_{8}$ (501.24): C, 55.09; H, 4.53; N, 13.97. Found: C, 54.84; H, 5.27; N, 14.19 .

1.13. $\mathrm{N}$-Ethyl- $\mathrm{N}$-(2-(2'-carboxyglutamic-bis- $\{4-0$-[6-0-amino-6deoxy-3,4-O-(isopropylidene)- $\beta$-D-galactopyranosyl]-2,3:5,6-di0 -isopropylidene-aldehydo-D-glucose dimethyl acetal\}-1' amido)ethyloxy)-4-(4-nitrophenyl-azo)aniline (2f)

$\mathrm{N}$-Methyl morpholine $(0.26 \mathrm{~mL}, 2.4 \mathrm{mmol})$ was added to a solution of $2 \mathbf{e}(0.5 \mathrm{~g}, 1.0 \mathrm{mmol})$ in THF $(5 \mathrm{~mL})$ and the mixture was stirred at room temperature for $5 \mathrm{~min}$. The resulting solution was cooled to $0{ }^{\circ} \mathrm{C}$, 2-chloro-4,6-dimethoxy-1,3,5-triazine (0.42 g, $\left.2.4 \mathrm{mmol}\right)$ was added and the mixture was stirred at room temperature. After $2 \mathrm{~h}$ the TLC indicated the formation of the activated intermediate $\left(R_{\mathrm{f}}=0.79,10: 0.4 \mathrm{CH}_{2} \mathrm{Cl}_{2}-\mathrm{CH}_{3} \mathrm{OH}\right)$ and the disappearance of the start$\operatorname{ing} \operatorname{acid}\left(R_{\mathrm{f}}=0.1\right)$. Amino lactose $4(1.0 \mathrm{~g}, 2 \mathrm{mmol})$ was added and the reaction mixture was slowly allowed to warm to room temperature and stirred overnight. TLC showed the formation of one major spot $\left(R_{\mathrm{f}}=0.35,10: 0.4 \mathrm{CH}_{2} \mathrm{Cl}_{2}-\mathrm{CH}_{3} \mathrm{OH}\right)$. The reaction mixture was evaporated to dryness under reduced pressure. The residue was dissolved in $\mathrm{CH}_{2} \mathrm{Cl}_{2}(20 \mathrm{~mL})$ and washed with a solution of $5 \%$ aq $\mathrm{HCl}(20 \mathrm{~mL})$ and $\mathrm{H}_{2} \mathrm{O}(3 \times 20 \mathrm{~mL})$. The organic solution was dried over $\mathrm{Na}_{2} \mathrm{SO}_{4}$ and filtered. The filtrate was concentrated under reduced pressure and the residue was purified by FCC, eluting with $95: 5 \mathrm{CH}_{2} \mathrm{Cl}_{2}-$ $\mathrm{CH}_{3} \mathrm{OH}$ to afford $2 \mathrm{f}(0.86 \mathrm{~g}, 60 \%)$ as red foam having $R_{\mathrm{f}} 0.4(95: 5$ $\mathrm{CH}_{2} \mathrm{Cl}_{2}-\mathrm{MeOH}$ ), mp 96-98 ${ }^{\circ} \mathrm{C}$ (chrom). $\delta$ 8.34-8.30 (m, 2H, 3'-H, 5'$\mathrm{H})$; 7.93-7.88 (m, 4H, 2'-H, 6'$\mathrm{CONHCH}), 7.22-7.19\left(\mathrm{~m}, 1 \mathrm{H}, \mathrm{CHCONHCH}_{2}\right), 6.81-6.78(\mathrm{~m}, 2 \mathrm{H}, 2-\mathrm{H}$, 6-H), 6.69-6.66 (m, $\left.1 \mathrm{H}, \mathrm{CH}_{2} \mathrm{CH}_{2} \mathrm{CONHCH}_{2}\right)$ 4.57-4,48 (m, 3H), 4.37-4.34 (m, 3H), 4.31-4.26 (m, 3H), 4.19-4.16 (m, 2H), 4.11$4.09(\mathrm{~m}, 1 \mathrm{H}), 4.08-3.97(\mathrm{~m}, 8 \mathrm{H}), 3.95-3.87(\mathrm{~m}, 4 \mathrm{H}), 3.83-3.69(\mathrm{~m}$, 7H), 3.63-3.37 (m, 17H), 3.25-3.18 (m, 1H), $3.14(\mathrm{~s}, 1 \mathrm{H}), 3.07(\mathrm{~s}$, 
1H), 2.43-2.12 (m, 3H), 2.03-1.91 (m, 1H), 1.48-1.38 (m, 12H), 1.32 $(\mathrm{s}, 12 \mathrm{H}), 1.29-1.25(\mathrm{~m}, 15 \mathrm{H}) .{ }^{13} \mathrm{CNMR}\left(50 \mathrm{MHz}, \mathrm{CDCl}_{3}\right): \delta 172.3(\mathrm{CO})$, 171.4 (CO), 169.0 (CO), 156.7, 151.2, 147.4, 143.7, 126.2, 124.6, 122.6, 111.4, (ArCH), 110.4 (2C), 110.2 (2C), 108.4 (2C), 108.2, 107.2, 103.4, 103.3, 78.9 (2C), 77.8, 77.5 (2C), 77.0, 76.8, 76.7 (2C), 76.6 (2C), 74.0, 73.9 (2C), 73.8, 72.4, 71.8, 70.7, 69.2 (2C), 64.5, 57.9, 57.4, 56.2, 56.0, 51.9, 49.8, 46.0, 40.4, 31.6, 29.0, 28.1 (2C), 27.2, 27.1, 26.4, 26.3, 26.2 (2C), 25.6 (2C), 24.0 (2C), 12.2. MS (ESI) $m / z=1480.41[\mathrm{M}]^{+}$. Anal. Calcd for $\mathrm{C}_{69} \mathrm{H}_{105} \mathrm{~N}_{7} \mathrm{O}_{28}$ (1480.60): C, 55.97; H, 7.15; N, 8.54. Found: C, 55.22; H, 6.94; N, 8.61.

\subsection{4. $N$-Ethyl- $N$-(2-(2'-carboxyglutamic bis[6' amidoyl-lactose]- 1 '-amido)ethyloxy)-4-(4-nitrophenyl-azo)aniline (2g)}

A solution of $\mathbf{2 f}(0.7 \mathrm{~g}, 0.47 \mathrm{mmol})$ in $90 \%$ aqueous TFA ( $5 \mathrm{~mL})$ was stirred at room temperature overnight. The TLC showed the disappearance of the starting material $\left(R_{\mathrm{f}} 0.4,95: 5 \mathrm{CH}_{2} \mathrm{Cl}_{2}-\mathrm{MeOH}\right)$ and the formation of a major spot with $R_{\mathrm{f}} 0.1$. The violet solution was repeatedly co-evaporated with toluene $(5 \times 25 \mathrm{~mL})$ at reduced pressure. The residue was treated with acetone $(10 \mathrm{~mL})$ at room temperature overnight and the fine suspension was centrifuged (1500 rpm) for $15 \mathrm{~min}$. The supernatant liquid was removed and the solid was dried in vacuo at room temperature to obtain $2 \mathbf{g}$ as a red powder $(0.42 \mathrm{~g}, 78 \%), \mathrm{mp} 145-148{ }^{\circ} \mathrm{C} .{ }^{1} \mathrm{H}$ NMR $(200 \mathrm{MHz}$, DMSO- $\left.d_{6}\right): \delta 8.32-7.92\left(\mathrm{~m}, 4 \mathrm{H}, 2^{\prime}-\mathrm{H}, 3^{\prime}-\mathrm{H}, 5^{\prime}-\mathrm{H}, 6^{\prime}-\mathrm{H}\right) ; 7.90-6.79$ $\left(\mathrm{m}, 4 \mathrm{H}, 8^{\prime}-\mathrm{H}, 9^{\prime}-\mathrm{H}, 11^{\prime}-\mathrm{H}, 12^{\prime}-\mathrm{H}\right), 5.08-4.57(\mathrm{~m}, 4 \mathrm{H}), 4.33-4.13$ $\left(\mathrm{m}, 3 \mathrm{H}, \quad \mathrm{OCH}_{2} \mathrm{CO}\right), 3.68-3.21\left(\mathrm{~m}, 6 \mathrm{H}, \mathrm{NCH}_{2} \mathrm{CH}_{2}, \mathrm{NCH}_{2} \mathrm{CH}_{3}\right.$, $\left.\mathrm{NCH}_{2} \mathrm{CH}_{2}\right), 2.31-2.26\left(\mathrm{~m}, 4 \mathrm{H}, \mathrm{CHCH}_{2}, \mathrm{CH}_{2} \mathrm{CO}\right), 1.24-1.14(\mathrm{t}, 3 \mathrm{H}$, $\left.J=7.0 \mathrm{~Hz}, \mathrm{NCH}_{2} \mathrm{CH}_{3}\right) .{ }^{13} \mathrm{C}$ NMR $\left(50 \mathrm{MHz}\right.$, DMSO- $\left.d_{6}\right): \delta 172.33$ $(2 \times \mathrm{CONH}), 168.66(\mathrm{CO}), 156.48,151.17,147.35,143.74,126.24$, 124.54, 122.57, 111.28, ( $\mathrm{ArCH}), 66.51\left(\mathrm{OCH}_{2} \mathrm{CO}\right), 61.44\left(\mathrm{NCH}_{2} \mathrm{CH}_{2}\right)$, $52.55(\mathrm{CH}), 48.71,45.62\left(\mathrm{NCH}_{2} \mathrm{CH}_{2}, \mathrm{NCH}_{2} \mathrm{CH}_{3}\right), 28.46,26.33$, $\left(\mathrm{CHCH}_{2}, \mathrm{CH}_{2} \mathrm{CO}\right) 12.28\left(\mathrm{NCH}_{2} \mathrm{CH}_{3}\right)$. MS (ESI) $m / z=1148.23[\mathrm{M}+1]^{+}$.
Anal. Calcd for $\mathrm{C}_{47} \mathrm{H}_{69} \mathrm{~N}_{7} \mathrm{O}_{26}$ (1148.08): C, 49.17; H, 6.06; N, 8.54. Found: C, 49.04; H, 5.87; N, 8.61.

\section{Acknowledgements}

We fully acknowledge Ente Cassa di Risparmio di Firenze for the grants that allowed us to buy the Varian-4000 spectrophotometer and the ThermoFisher LCQ-Fleet Esi-Mass apparatus.

\section{References}

1. (a) Bianchini, R.; Bartalucci, G.; Catelani, G.; Seu, G. European Patent Application n. 04005253.4 deposit 03/05/2004.; (b) Bartalucci, G.; Bianchini R.; Catelani, G.; D’Andrea, F.; Guazzelli, L. Eur. J. Org. Chem. 2007, 588-595; (c) Isaad, J.; Bianchini, R.; Catelani, G.; Frino, E.; Rolla, M. BioResources 2007, 2, 630-637; (d) Bianchini, R.; Catelani, G.; Isaad, J.; Cecconi, R.; D’Andrea, F.; Guazzelli, L.; Rolla, M. Eur. J. Org. Chem. 2008, 444-454.

2. Corsi, M.; Bonanni, M. 'Colbiotech Project', POR CREO FSE 2007-2013 Ob. 2fellowship, annual report, The University of Florence, unpublished results, 2010.

3. (a) Greenshields, J. N.; Hull, G.; Tury, B. US Patent 3957433, 18/05/1976.; (b) Dilling, P. US Patent 4131564, 26/12/1978.; (c) Indictor, N.; Koestler, R. J.; Sheryll, R. J. Am. Inst. Conserv. 1985, 24, 104; (d) Barni, E.; Savarino, P.; Viscardi, G. Acc. Chem. Res. 1991, 24, 98-103.

4. Isaad, J.; Rolla, M.; Bianchini, R. Eur. J. Org. Chem. 2009, 2748-2764.

5. (a) Banat, I. M.; Nigam, P.; Singh, D.; Marchant, R. Bioresour. Technol. 1996, 58 217-227; (b) Stolz, A. Appl. Microbiol. Biotechnol. 2001, 56, 69-80; (c) Vijayaraghavan, K.; Lee, M. W.; Yun, Y. S. Bioresour. Technol. 2008, 99, 57785785. and references cited therein.

6. Albertson, N. F. Org. React. 1962, 12, 157-355.

7. Allen, C. F. H.; Byers, J. R.; Humphlett, W. J. Org. Synth. 1963, Coll. Vol. 4, 739 .

8. Bianchini, R.; Catelani, G.; Isaad, J.; Cecconi, R.; D’Andrea, F.; Frino, E.; Rolla, M. Carbohydr. Res. 2008, 343, 2067-2074.

9. Barili, P. L.; Catelani, G.; D’Andrea, F.; De Rensis, F.; Falcini, P. Carbohydr. Res. 1997, 16, 1001-1010

10. Falchi, A.; Giacomelli, G.; Porcheddu, A.; Taddei, M. Synlett 2000, 275-277.

11. Still, W. C.; Kahn, M.; Mitra, A. J. Org. Chem. 1978, 43, 2923-2932. 